\title{
GENETIC CONTROL OF SEED SIZE IN COWPEA (Vigna unguiculata (L.) Walp)
}

\section{EGBADZOR K.F. ${ }^{1,2 *}$, DADOZA M. ${ }^{3}$, DANQUAH E.Y. ${ }^{1}$, YEBOAH M. ${ }^{1}$, OFFEI S.K. ${ }^{5}$ AND OFORI K. ${ }^{4}$}

1West Africa Centre for Crop Improvement, University of Ghana, Legon, Accra, Ghana.

${ }^{2}$ CSIR - Plant Genetic Resources Research Institute, Bunso, E.R. Ghana.

3Ministry of Food and Agriculture, Ketu North District, V.R. Ghana.

${ }^{4}$ Department of Crop Science, University of Ghana, Legon, Accra, Ghana.

5The Biotech Centre, University of Ghana, Legon, Accra, Ghana.

*Corresponding Author: Email- kenfafa@yahoo.com

\section{Received: September 30, 2013; Accepted: October 18, 2013}

\begin{abstract}
Seed size contributes to yield and it is also a consumer trait of cowpea in Ghana and other parts of the world. Ghanaian consumers tend to prefer large seeded cowpea to small sizes although, Ghanaian varieties have smaller seeds compared to the imported types. This might be a contributing factor to high importation of cowpea to Ghana. To breed cowpeas with large grains, it is paramount to understand the inheritance of the trait. Generation mean analysis was performed to estimate gene actions on seed size of cowpea using CB27 and Gh3710 as the large and small seeded parents respectively. It was observed that eight genes control seed size and that small seed is partially dominant over large seed. The estimated broad sense heritability was $84 \%$ while the narrow sense was $35 \%$. Both additive and non-additive genes with their interactions in the exception of additive - additive had significant effect on seed size inheritance in cowpea. The inheritance of seed size was observed to be complex, it was suggested that combinations of methods such as single seed descent and backcross methods with selection from early generations through advanced level would help improve seed size of cowpea.
\end{abstract}

Keywords- Additive Gene, Cowpea, Dominance, Generation Mean, Heritability, Seed size

Citation: Egbadzor K.F., et al (2013) Genetic Control of Seed Size in Cowpea (Vigna unguiculata (L.) Walp). International Journal of Agriculture Sciences, ISSN: 0975-3710 \& E-ISSN: 0975-9107, Volume 5, Issue 2, pp.-367-371.

Copyright: Copyright@2013 Egbadzor K.F., et al. This is an open-access article distributed under the terms of the Creative Commons Attribution License, which permits unrestricted use, distribution and reproduction in any medium, provided the original author and source are credited.

\section{Introduction}

Seed size is of interest to many people for the reason that $70-80 \%$ of the world's food calories and $60-70 \%$ protein consumed by man come from seeds [1]. The effort to increase the number of seeds or their sizes relates to increasing food production [2]. The genetic control of the final seed size is complex as a number of factors, although, discovered (mainly in Arabidopsis thaliana), the control of the trait is not well understood. According to Sundaresan [3] three different genes are involved in endosperm size control with IKU1 acting upstream of MINI3 and IKU2. A factor named GW2 was discovered in rice to induce cell proliferation in grains thereby increasing its size [4]. Li, et al [5] reported that "DA1 plays a major role in setting final sizes of both seeds and organs by restricting the duration of proliferative growth". In addition to AUXIN RESPONSE FACTOR2, APETALA2, and DA1, Adamski, et al [6] reported KLU which acts independently of other maternal factors to influence seed coat cell proliferation. EOD3 and CYP78A9 gene families were reported to control seed size in Arabidopsis in both overlapping and distinct manner [7].

Each of the three major components of a seed namely; the seed coat, the endosperm (cotyledon) and the embryo contribute to its final size. The integument (seed coat) determines the maximum volume the seed can grow [7]. The size of the integument itself is specified by its cell number and size [2]. In most plants, the endosperm is the major contributor to the volume of the mature seed; however, in Arabidopsis and some other dicots, the endosperm is consumed, being replaced by the embryo, which then constitutes most towards the mature seed size [3].

Cowpea seed size which is an important component of seed yield is also an essential market trait as consumers in Ghana tend to prefer larger seeds to smaller ones [8]. Survey in some markets in Ghana has revealed that the varieties in cultivation in the country generally smaller seeds than imported ones. It will therefore be imperative to breed larger seeded cowpea. However, the mode of inheritance of the trait must first be understood before setting it as a breeding goal.

Inheritance of seed size of cowpea has been of interest to plant breeders for very long time. Drabo, et al [9] indicated that contradictory reports have been given on inheritance of seed size in cowpea since 1950. They also reported that cowpea seed weight (size) is governed by many genes acting mainly additively with small size partially dominant over large. Additive gene effect is desirable as progress can be made through selection. Yilwa [10] reported large seed to be dominant over small seed, continuing the contradiction 
and therefore warranting the study of the trait among genotypes available to the individual for cowpea improvement purposes.

Cowpea seed is formed through the process of double fertilization as in angiosperms. The size of the seed formed following double fertilization is affected by maternal, paternal and positional effects jointly [11]. The positional effect is the contribution of the zygote to the seed size.

Relationship between genetic effects and the way traits are transmitted from parents to their progenies is important in crop improvement. Several genetic designs have been developed to measure the relative importance of additive, dominance and epistasis which are the main gene actions in the expression of quantitative traits like seed size. Generation mean analysis proposed by Mather and Jinks is a design favored by breeders and geneticists working with selfpollinated species [12].

\section{Materials and Methods}

Cowpea genotypes, CB27 and Gh3710 with respective seed weights of - and - were used for the experiment. CB27 was obtained from the University of California Riverside while Gh3710 was obtained from CSIR-PGRRI. Both genotypes flowered about the same number of days after planting (32 days). The parents were crossed and subsequently the generations, $F_{1}, F_{2}, B_{1}, B C_{2}$ together with the parents used for generation mean analysis for seed size. The experiment was conducted at Ohawu [Latitude = $6^{*} 03^{\prime} 50.74812$ 'N; Longitude $=0{ }^{*} 54^{\prime} 49.85784$ "E] in the coastal savanna of Ghana in 2013.

The experiment was conducted on field under rain-fed condition. The experiment was laid in a randomized complete block design with 10 replications for the parents and $F_{1}$ populations while the Backcrosses and $F_{2}$ were replicated 30 and 60 times respectively. The between row spacing was $100 \mathrm{~cm}$ and the within row $50 \mathrm{~cm}$, while between block was $200 \mathrm{~cm}$.

One hundred seed mass per plant was weighed with a digital scale in grams.

\section{Results}

\section{Differences in Seed Weight of Various Generations}

Analysis of variance showed significant differences between 100 seed weight of the various generations of plants used as treatments. Boxplot of the seed weight is shown in [Fig-1].

The means and standard errors (SE) of the various generations are shown in [Table-1].

Table 1- Average of 100 seed weight (g) and standard errors for various cowpea generations with a matrix showing LSDs (5\%) with non-significant pairs indicated with asterisks $\left(^{*}\right)$

\begin{tabular}{|c|c|c|c|c|c|c|c|}
\hline Generation & Mean \pm SE & \multicolumn{6}{|c|}{ LSD } \\
\hline $1\left(\mathrm{BCP}_{1}\right)$ & $16.79 \pm 0.2340$ & - & & & & & \\
\hline $2\left(\mathrm{BCP}_{2}\right)$ & $13.52 \pm 0.2340$ & 0.63 & - & & & & \\
\hline $3\left(F_{1}\right)$ & $15.92 \pm 0.4243$ & $0.97^{*}$ & 0.97 & - & & & \\
\hline $4\left(F_{2}\right)$ & $15.98 \pm 0.1892$ & 0.63 & 0.63 & $0.97^{*}$ & - & & \\
\hline 5 [CB27 $\left.\left(\mathrm{P}_{1}\right)\right]$ & $22.58 \pm 0.4243$ & 0.97 & 0.97 & 1.1 & 0.97 & - & \\
\hline \multirow[t]{2}{*}{$6\left[\mathrm{Gh} 3710\left(\mathrm{P}_{2}\right)\right]$} & $11.20 \pm 0.4243$ & 0.97 & 0.97 & 1.1 & 0.97 & 1.1 & - \\
\hline & Generation & 1 & 2 & 3 & 4 & 5 & 6 \\
\hline
\end{tabular}

Matrix pairing of the generations is also shown in the Table and the generations with significant differences in 100 seed weight indicated with asterisks. There were only two non-significant pairs of generations; $F_{1}$ against $F_{2}$ and $\mathrm{BCP}_{1}$.

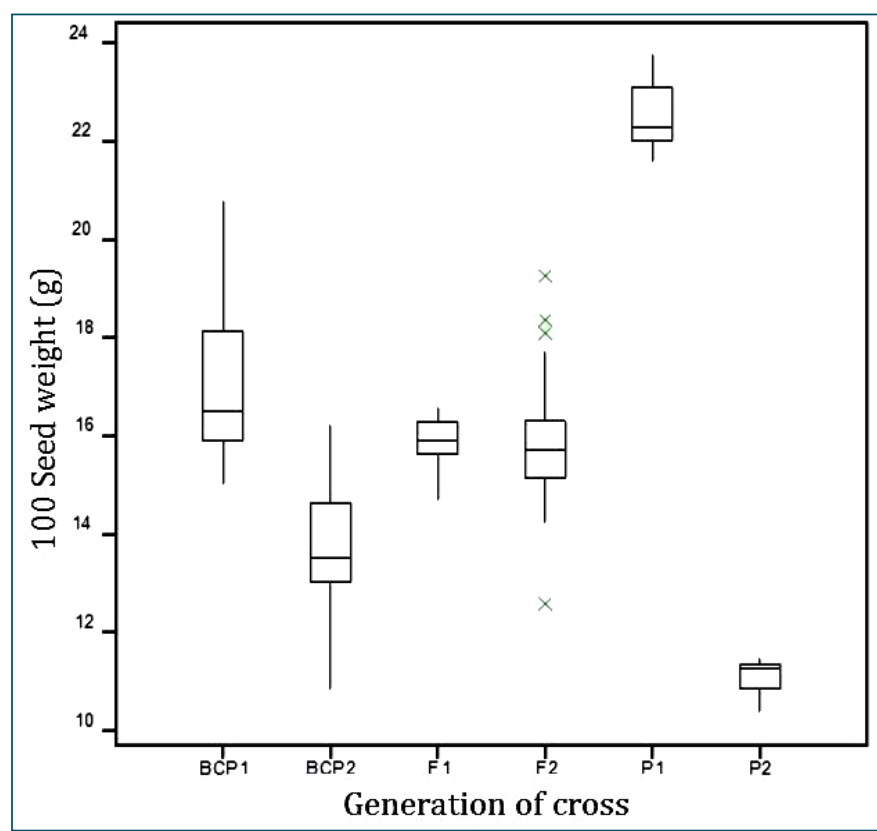

Fig. 1- Boxplot of 100 seed weight (g) of different generation of cowpea

\section{Heritability of 100 Seed Weight in the Broad Sense}

Broad sense heritability $\left(\mathrm{H}^{2}\right)$, of 100 seed weight of cowpea was estimated by the formula of Ito \& Brewbaker [13] as shown in [Eq1].

$$
\mathrm{H}_{\mathrm{b}}^{2}=\left(V \mathrm{~F}_{2}-\mathrm{VE}\right) / V \mathrm{~F}_{2} \text { : }
$$

where,

$$
\begin{aligned}
& H_{b}^{2}=\text { Broad sense heritability } \\
& V E=\text { Error variance }=V 4\left(V P_{1}+V P_{2}+2 V F_{1}\right)=0.39255 \\
& V F_{2}=\text { Variance of } F_{2} \text { family }=2.4722 \\
& V P_{1}=\text { Variance of parent } 1=0.3686 \\
& V P_{2}=\text { Variance of parent } 2=0.2084 \\
& V F_{1}=\text { Variance of } F_{1} \text { family }=0.4966 \\
& H_{b}^{2}=0.84
\end{aligned}
$$

The estimated broad sense heritability for 100 seed weight is therefore $84 \%$.

\section{Narrow Sense Heritability}

The method of Warner [14] was used to estimate narrow-sense heritability $\left(h^{2} \mathrm{~ns}\right)[\mathrm{Eq}-2]$

$$
h^{2} n s=\left[2 V F_{2}-\left(V B C P_{1}+V B C P_{2}\right)\right] / V F_{2}
$$

where,

$V F_{2}, V B C P_{1}$ and $V B C P_{2}$ are the variances of the $F_{2}, C B 27 / F_{1}$ and Gh3710/F 1 respectively.

$$
\begin{aligned}
& V F_{2}=2.472 \\
& V B C P_{1}=2.54 \\
& V B C P_{2}=1.539 \\
& h^{2} n s=0.35
\end{aligned}
$$

The estimated narrow sense heritability for 100 seed weight is therefore, $35 \%$. 


\section{Number of Effective Factors (Genes)}

The number of effective factors controlling seed weight was estimated using the method of Burton [15], shown in [Eq-3]

$$
k=\left[0.25\left(0.75-h+h^{2}\right) D^{2}\right] /\left(V F_{2}-V F_{1}\right)
$$

where,

$D=P_{1}-P_{2}:=11.38$

$\mathrm{h}=\left(\mathrm{F}_{1}-\mathrm{P}_{2}\right) / \mathrm{P}_{1}-\mathrm{P}_{2}=0.4148$

$k=$ minimum number of effective factorsl

$\mathrm{VF}_{2}=$ Variance of $\mathrm{F}_{2}$ population $=2.47222$

$\mathrm{V}^{2} \mathrm{~F}_{1}=$ Variance of $\mathrm{F}_{1}$ population $=0.4966$

$\mathrm{P}_{1}=$ mean of parent $1=22.58$

$\mathrm{P}_{2}=$ mean of parent $2 .=22.58$

Number of effective factors controlling seed mass $=8$

\section{The Degree of Dominance}

The degree of dominance is the deviation from the mid-parent value towards one of them as illustrated [Fig-2].

\begin{tabular}{|c|c|c|c|c|}
\hline $\bar{P}_{1}$ & & $1 / 2\left(\bar{P}_{1}+\bar{P}_{2}\right)$ & $\bar{F}_{1}$ & $\overline{P_{2}}$ \\
\hline 22.58 & & 16.89 & 15.98 & 11.2 \\
\hline & -a & & $+a$ & \\
\hline
\end{tabular}

Fig. 2- Diagrammatic representation of the genotypic values based on Falconer [16]

$$
\begin{aligned}
d & =F 1-1 / 2(P 1+P 2) \\
& =15.98-1 / 2(22.58+11.2) \\
& =-0.91 P 2 \text { is dominant over } P 1 \text { making d negative } \\
a & =1 / 2(P 1-P 2) \\
& =5.69
\end{aligned}
$$

Degree of dominance $=\mathrm{d} / \mathrm{a}=0.1599=16 \%$

The mean value, that is, the $\mathrm{F} 1$ value is closer to the smaller seeded variety than to the larger which means that the former is the dominant variety.

\section{Gene Action Controlling 100 Seed Weight}

Generation mean analysis was used to estimate genetic control of seed weight in cowpea

The GMA model is stated below:

$$
Y=m+\alpha a+\beta d+\alpha^{2} a a+2 a \beta a d+\beta^{2} d d
$$

$\alpha$ and $\beta$ are the coefficients for $a$ and $d$, respectively.

$Y=$ the observed mean

$\mathrm{m}=$ mean $=$ mean of the $\mathrm{F} 2$

$a=$ pooled additive effects

$d=$ pooled dominance effects

$\mathrm{aa}=$ additive $\mathrm{x}$ additive gene interaction effects

$\mathrm{ad}=$ additive $\mathrm{x}$ dominance gene interaction effects

$\mathrm{dd}=$ dominance $\mathrm{x}$ dominance gene interaction effects

The mode of inheritance of 100 seed weight in cowpea was estimated by generation mean analysis with six generations $\left(P_{1}, P_{2}, F_{1}\right.$, $F_{2}, B C P_{1}$ and $B C P_{2}$ ) of $C B 27$ and $G$ 3710. Following significant differences in 100 seed weight of the various generations, their means and variances were used to perform generation mean. Vital results from regression analysis from SAS are presented in [Table2]. The generation mean analysis indicated that there were additive and dominance gene effects and their interactions in the inheritance of the trait.

Table 2- Analysis of variance and parameter estimates for genetic control of 100 seed weight of cowpea obtained through generation mean analysis with CB27 and Gh3710.

$\begin{array}{lccccccc}\text { Variable } & \text { DF } & \begin{array}{c}\text { Parameter } \\ \text { Estimate }\end{array} & \begin{array}{c}\text { Standard } \\ \text { Error }\end{array} & \text { t Value } & \text { Pr }>|\mathbf{t}| & \text { Type I SS } & \text { Type II SS } \\ \text { Intercept } & 1 & 18.747 & 1.722 & 10.89 & <.0001 & 100712 & 487.836 \\ \text { Rep } & 1 & 0.008 & 0.012 & 0.65 & 0.5151 & 0.743 & 1.753 \\ \text { a } & 1 & -5.678 & 0.217 & -26.21 & <.0001 & 3196.69 & 2828.02 \\ \text { d } & 1 & -9.706 & 3.469 & -2.8 & 0.0058 & 39.062 & 32.234 \\ \text { aa } & 1 & -1.99 & 1.682 & -1.18 & 0.2387 & 36.671 & 5.763 \\ \text { ad } & 1 & 4.775 & 0.674 & 7.09 & <.0001 & 200.316 & 206.906 \\ \text { dd } & 1 & 6.61 & 1.917 & 3.45 & 0.0007 & 48.964 & 48.964 \\ \text { Note: (a) additive; (d) dominance; (aa) additive-additive; (ad) additive-dominance; } \\ \text { (dd) dominance-dominance gene effects. }\end{array}$

\section{Discussion}

Significant differences were observed between the various generations of plants from the cross of CB27 and Gh3710 in terms of 100 seed weight. The means of $F_{1}, F_{2}$ and the backcrosses fell between the two parental means of $11.2 \mathrm{~g}$ and $22.58 \mathrm{~g}$, showing no transgressive segregates. This result is similar to that of Lopez, et al [17], although, comparably each of their generations had smaller weight with their small and large seeds having 100 seed weight of $4.82 \mathrm{~g}$ and $15.14 \mathrm{~g}$ respectively. Lucas, et al [18] on the other hand used slightly heavier genotypes (11.6g and $26.41 \mathrm{~g}$ ) as the parents in QTL studies for seed size.

The broad sense heritability estimated for 100 seed weight in this research was $84 \%$. This value is very close to $83.3 \%$ reported [19]. Drabo, et al [9] also reported heritability estimate of $85 \%$ while Manggoel, et al [20] reported $86.84 \%$. Omoigui, et al [21] and Tchiagam, et al [22], however, reported broad sense heritability as high as $98.9 \%$ and $90 \%$ respectively for the trait. Egbadzor, et al [23], however, used association mapping with SNP markers and reported $96 \%$ broad sense heritability for 100 seed weight in cowpea.

The low narrow sense heritability observed may have been caused by the significant additive dominance and dominance dominance epistatic effects. However, such low narrow sense heritability has been reported: Adeyanju, et al [24] for example reported 15 and $25 \%$ from two different crosses. Relatively higher narrow sense heritability for 100 seed weight of $67 \%$ was reported for cowpea by Tchiagam, et al [22]. These reports suggest that breeding methodology to improve seed size in cowpea may be influenced by the genotype and environment in which the breeding is to take place.

Findings in this experiment confirm that of Drabo, et al [9] that small seed size is partially dominant over larger seed. Partial dominance genetic variance was evident in that the $F_{1}$ of CB27/Gh3710 resembled Gh3710 more than CB27 in terms of seed size. This means that small seed size is partially dominant over large seed. Dominance gene effect was observed to be important in seed size inheritance in lentil as well [25]. However, the finding in this experiment was contrary to the observation of Lopez, et al [17] who stated that large seed in cowpea is rather partially dominant over the small. These contradictory findings may be due to the genotypes used in the various studies. It was also observed that seed from none of the 
generations namely: $\mathrm{P}_{2}, \mathrm{~F}_{1}, \mathrm{~F}_{2}, \mathrm{BCP}_{1}$ or $\mathrm{BCP}_{2}$ equaled the weight of $P_{1}$ (CB27). Similarly, Fatokun, et al [19] had no $F_{2}$ seeds as heavy as the heavy parent used in their experiment.

The number of gene pairs estimated to control seed weight was eight, the exact number reported by Drabo, et al [9] in spite of different genotypes used in the separate trials. Lopez, et al [17], however, estimated five factors. The genetic effect of these genes, being it additive, dominant or their interactions would determine progress that could be made in breeding.

Additive and non-additive gene effects with their interactions were shown to significantly control seed size in cowpea in the exception of additive - additive (aa) in the current experiment. This means that (a), (d), (ad) as well as (dd) were significant. However, the magnitude of the significant fixable gene action (a) has smaller magnitude compared with the non-fixable (d), (ad) and (dd)) [26]. Gene interaction observed was "duplicate" because (d) was negative while (dd) was positive [25]. The negative (d) also shows that small seed is dominant over large seed. The presence of two or more of the eight factors estimated to control seed size in this experiment would act in duplicate manner [27] to affect the trait. Although, (aa) gene effect was not significant, the associated negative sign indicates the dispersion of seed weight genes in both parents (CB27 and Gh3710).

Significant (a) gene effect is an assurance that gains can be made with selection in the long term [28] and in this case for seed size in cowpea. Seeds of the backcross generations in this experiment are indication of the practicality of this principle by being significantly larger or smaller than the $F_{1} s$. The backcross to the larger seeded parent (CB27) resulted in larger seeds while the $F_{1}$ crossed to the small seeded parent (Gh3710) were also smaller than the $F_{1}$.

Both fixable and non-fixable gene effects are important and therefore make breeding for cowpea seed size complex. The presence of significant (a) gene effect would make selection from early generation effective while selection at advanced generations would also be effective because of significant (ad) and (dd). The implication is that selection for seed size for cowpea should commenced from the segregation population through advanced level where varieties are at evaluation stage.

\section{Conclusion}

It was observed in the experiment that eight genes control 100 seed weight in cowpea using the genotypes CB27 and Gh3710 as parents in generation mean analysis. Small seed size in partially dominant over large seed. Additive, dominant, additive - dominant and dominant - dominant gene actions were found to be significant. The inheritance of seed weight is complex and suggesting that a combination of different approaches to improve the trait is a panacea to succeed contrary to the use of a single approach. Such methods as combination of single seed descent and backcrosses with selection from early generation through to advanced state may be used to make progress.

\section{Acknowledgement}

The authors thank Alliance for a Green Revolution in Africa (AGRA) for providing the financial support for this research. They also expressed appreciation for the support given by staff of Ketu - North District of the Ministry of Food and Agriculture, Ghana, especially their director, Mr. Samuel Laryea - Tetteh. Last but not the least, staff of CSIR - PGRRI, notably, Messrs.' Daniel Ashie Kotey and Dickson Gamedoagbao are commended for their support.

\section{Conflict of Interest: None declared.}

\section{References}

[1] Lu J., Zhanga C., Baulcombe D.C. and Chen Z.J. (2012) Proceedings of the National Academy of Sciences, 109(14), 55295534.

[2] Herridge R.P., Day R.C., Baldwin S. and Macknight R.C. (2011) Plant Methods, 7(1), 3.

[3] Sundaresan V. (2005) Proceedings of the National Academy of Sciences, 102(50), 17887-17888.

[4] Song X., Huang W., Shi M., Zhu M. and Lin H. (2007) Nature Genetics, 39(5), 623-630.

[5] Li Y., Zheng L., Corke F., Smith C. and Bevan M.W. (2008) Genes Dev., 22(10), 1331-1336.

[6] Adamski N.M., Anastasiou E., Eriksson S., O'Neill C.M., Lenhard M. (2009) Proceedings of the National Academy of Sciences, 106(47), 20115-20120.

[7] Fang W., Wang Z., Cui R., Li J., Li Y. (2012) The Plant Journal, 70(6), 929-939.

[8] Langyintuo A.S., Lowenberg-DeBoer J., Faye M., Lambert D., Ibrod G., Moussa B., Kergna A., Kushwaha S., Musa S. and Ntoukam G. (2003) Field Crops Research, 82(2) 215-231.

[9] Drabo I., Redden R., Smithson J.B. and Aggarwal V.D. (1984) Euphytica, 33, 929-934.

[10]Yilwa V. (2012 Genetics of Cowpea - Inheritance of Qualitative and Quantitative Traits, Lambert Academic Publishing, 175-178.

[11]House C., Roth C., Hunt J. and Kover P.X. (2010) Proceedings of the Royal Society B: Biological Sciences, 277(1695), 28852893.

[12]Piepho H.P and Mohring J. (2010) Crop Science, 50, 16741680.

[13].Ito G.M. and Brewbaker J.L. (1991) J. Amer. Soc. Hort. Sci., 116, 1072-1077.

[14]Warner J.N. (1952) Agron. J., 44, 427-430.

[15]Burton W.G. (1951) Agronomy Journal, 43, 409-417.

[16]Falconer D.S. and Mackay T.F.C. (1996) Introduction to Quantitative Genetics, Pearson Education Itd, England.

[17]Lopes F.C.C., Gomes R.L.F. and Filho F.R.F. (2003) Scientia Agricola, 60(2), 315-318.

[18]Lucas M.R., Huynh B.L., Vinholes P.S., Cisse N., Drabo I., Ehlers J.D., Roberts P.A., Close T.J. (2013) Frontiers in Plant Sciences, 4(95), doi: 10.3389/fpls.2013.00095.

[19]Fatokun C.A., Menancio-Hautea D.I., Danesh D. and Young N.D. (1992) Genetics, 132, 841-846.

[20]Manggoel W., Uguru M.I., Ndam O.N. and Dasbak M.A. (2012) Journal of Plant Breeding and Crop Science, 4(5), 80-86.

[21]Omoigui L.O., Ishiyaku M.F., Kamara A.Y., Alabi S.O., Mohammed S.G. (2006) African Journal of Biotechnology, 5(13), 11911195.

[22]Tchiagam J.B.N., Bell J.M., Ngakeu D.F., Njintang N.Y. and Youmbi E. (2011) Agric. Biol. J. N. Am., 2(4), 698-707.

[23]Egbadzor K.F., Yeboah M., Danquah E.R., Ofori K and Offei S.K. (2013) Int. J. Plant Breed. Genet., 7(2), 115-123. 
[24]Adeyanju A.O., Ishiyaku M.F., Echekwu C.A. and Olarewaju J.D. (2012) African Journal of Biotechnology, 11(46), 1047310483.

[25]Khodambashi M., Bitaraf N. and Hoshmand S. (2012) J. Agr. Sci. Tech., 14, 609-616.

[26] Hakizimana F., Ibrahim A.M.H., Langham M.A.C., Rudd J.C. and Scott D. (2004) Euphytica, 139, 133-139.

[27]Suzuki D.T., Griffiths A.J.F., Miller J.H. and Lewontin R.C. (1989) An Introduction to Genetic Analysis, W.H. Freeman and Company, New York. P83.

[28]Acquaah G. (2007) Principles of Plants Genetics and Breeding, Blackwell Publishing.

[29]Fatokun C.A. (2002) Proceedings of the World Cowpea Conference III, IITA, Ibadan, Nigeria.

[30]Park S.O., Coyne D.P., Jung G., Skroch P.W. Arnaud-Santana E., Steadman J.R., Ariyarathne H.M. and Nienhuis J. (2000) J. Amer. Soc. Hort. Sci., 125(4), 466-475. 